\title{
Health Tourism: Opportunities, Constraints, Obstacles and Solutions
}

\author{
Mehrnoosh Jafari ${ }^{1}$, Mohammadkarim Bahadori ${ }^{2}$, , Ramin Ravangard $^{3}$ \\ ${ }^{1}$ Department of Health Services Management, Tehran North Branch, Islamic Azad University, Tehran, IR Iran \\ ${ }^{2}$ Health Management Research Center, Baqiyatallah University of Medical Sciences, Tehran, IR Iran \\ ${ }^{3}$ Department of Health Services Management, School of Management and Medical Information Sciences, Shiraz. University of Medical \\ Sciences, Shiraz, IR Iran
}

"Corresponding Author: Mohammadkarim Bahadori, Associate Professor of Health Care Management, Health Management Research Center, Baqiyatallah University of Medical Sciences, Mollasadra Street, Tehran, Iran. Tel: +98.2182482417, Fax: +98.2188057022, E-mail: bahadorihealth@gmail.com

Article History: Received: 2 Jan. 2016; Accepted: 15 Jan. 2016; Online Published: 10 Apr. 2016

Cite this article as: Jafari M, Bahadori M, Ravangard R. Health tourism: opportunities, constraints, obstacles and solutions. Int J Travel Med Glob Health. 2016;4(1):378

\section{Dear Editor}

Tourism is an economic activity which, because of its special features, creates the possibility of using natural resources for all nations of the world, regardless of their level of development [1]. In the industry classification, tourism is the third largest industry in the world after the oil and automobile industries. According to a UN report, one of the most important tools of economic development and income generation is the tourism industry. Statistics indicate that 750,000 American tourists have traveled outside their country to receive medical treatment. Other statistics show that about 40 percent of the health sector income is obtained from health tourism, and statistical estimates represent that the income earned from health tourism in the world will be a trillion, five hundred and ninety million dollars in 2020 [2].

Recently, health tourism in its three forms of wellness tourism, medical tourism, and curative tourism has become very popular for various reasons, including the high costs of living in industrialized countries, the considerable and high time of responsiveness and accountability of these countries' healthcare systems, and the existence of rich natural resources in other countries [3].

Compared with other countries in the region, Iran can become a country suitable for health tourism, because it has high ecological diversity and the nature of the four seasons, rich and abundant natural resources, mineral water springs, skilled and experienced physicians and nurses, and affordable and low cost healthcare services. However, some restrictions hinder the growth of this important health industry in Iran, including:

The oil-based economy that creates no need for tourism revenue, lack of public awareness about tourism, lack of awareness about appropriate hosting; the underdevelopment of a transportation infrastructure, inefficient and ineffective airline services, poor hospitality system and the significant differences between industry indices and standards in Iran and internationally, religious and ideological differences and concomitant legal restrictions, unfamiliarity of many tourists with the limitations and restrictions of the host country, lack of macroeconomic policies and this industry's very small share of GNP, lack of necessary supervision, lack of infrastructural institutions to improve the quality of hospital services and service providers, lack of the necessary knowledge and skills among employees of the transportation system, hotels and hospitals and their lack of English proficiency, deficiencies and weaknesses of research and training in this area, political constraints such as sanctions and cutting of political-economic ties and cooperation with other countries of the world, weaknesses of services related to visa issuance, weaknesses and lack of proper organization of travel agencies for issuing visas and providing tourist services, lack of proper medical equipment and instruments in hospitals, lack of attention to the key role of this industry in increasing gross national income, having high financial turnover, and creating productive employment with a high profit margin [1, 2, 4].

So what to do?

Some solutions for improving Iran's health tourism industry can be proposed as follows:

a resurgence of the Iranian brand of tourism, cultural industries and health tourism attractions in target markets; formation of a special committee to develop health tourism; marketing and advertising exhibitions held in target countries to introduce Iran's attractions in this regard; documentation of the national development of health tourism; creation of shared offices with active companies in the field of health tourism in candidate countries; design and development of solutions for accepting supplementary insurance from target countries; more attention to hospital accreditation and increases in the quality of services provided by hospitals; strengthening of trained and skilled staff to provide services to tourists; strengthening of the hospitality industry; development of joint contracts between the Ministry of Health and the hospitality industry to strengthen and prepare hotels for admitting patients and their families; issuance of media advertisements and provision of a cultural infrastructure to attract tourists to the country; allocation of sufficient budget resources for restoring natural resources and natural potential resources of health; establishment of working groups to discover hidden natural resources; creation of memoranda and contracts between the Ministry of Health and prestigious universities in the world to dispatch healthcare staff, including physicians, nurses and other health professionals to leading countries in the field of health tourism such as the Philippines, India, Thailand, Malaysia, Singapore, etc. in order to receive training and to enhance the necessary skills in this regard; and the establishment and strengthening of study fields related to this area in the country's universities. 


\section{References}

1. Mojarradi Z, Amouzegar S, Beikzadeh S, Milani M, Izanloo A, Khoramehr G. Health Tourism Inclined Toward Obtaining Accreditation. Razavi Int J Med. 2014;2(4):e20047.

2. Izadi M, Saadat SH, Ayoubian A, Dehaghi ZH, Karbasi MR, Jalali AR. Health tourism in Iran; identifying obstacles for development of this industry. Int J Travle Med Glob Health. 2014;1(2):89-94.
3. Sobouti H, Alavi P. Analyze the strengths and weaknesses of rural tourism based on SWOT model in order to strategic planning (case study: Tarom province, Zanjan, Iran). Int J Sci Basic Appl Res. 2015;4(7):408-18.

4. Pocock NS, Phua KH. Medical tourism and policy implications for health systems: a conceptual framework from a comparative study of Thailand, Singapore and Malaysia. Global Health. 2011;7(1):1. 